\title{
STUDI POTENSI SIANIDIN DAN PEONIDIN DARI UBI JALAR UNGU (Ipomoea Batatas L.) SEBAGAI AGEN DEPIGMENTASI SECARA IN SILICO
}

\author{
N P. L. Laksmiani"' I G. P. Putra, I P. W. Nugraha, I W. Suwartawan, dan N K. S. Ani \\ Program Studi Farmasi, Fakultas Matematika dan Ilmu Pengetahuan Alam, Universitas Udayana \\ *Email: lindalaksmiani@gmail.com
}

\begin{abstract}
ABSTRAK
Hiperpigmentasi disebabkan oleh adanya peningkatan produksi melanin yang menyebabkan penggelapan warna kulit. Ubi ungu merupakan salah satu tanaman yang berpotensi dikembangkan sebagai agen depigmentasi kulit karena mengandung antosianin. Jenis antosianin yang paling banyak terkandung dalam umbi ubi jalar ungu adalah sianidin dan peonidin yang secara in vitro terbukti dapat digunakan sebagai pencerah kulit. Penelitian ini bertujuan untuk mengetahui potensi dari sianidin dan peonidin sebagai agen depigmentasi kulit terhadap protein target D-Dopachrome taumerase secara in silico melalui metode molecular docking. Tahapan penelitian yang dilakukan meliputi preparasi protein target menggunakan aplikasi Chimera 1.10.1, optimasi struktur 3D sianidin dan peonidin menggunakan aplikasi Hyperchem 8, serta validasi metode molecular docking dan docking senyawa sianidin dan peonidin pada protein target menggunakan aplikasi Autodock 4.2. Hasil penelitian yang didapatkan adalah energi ikatan yang terbentuk antara sianidin dan peonidin terhadap protein target $D$ Dopachrome taumerase. Nilai energi ikatan sianidin dan peonidin terhadap protein target D-Dopachrome taumerase yang didapatkan adalah $-7,75 \mathrm{kkal} / \mathrm{mol}$ dan $-8,38 \mathrm{kkal} / \mathrm{mol}$. Nilai energi ikatan sianidin dan peonidin yang didapatkan lebih kecil dibandingkan dengan native ligand yang menunjukkan ikatan yang terbentuk antara senyawa uji (sianidin dan peonidin) dengan protein terget lebih kuat dan stabil dibandingkan dengan native ligand, sehingga afinitas senyawa uji lebih besar dibandingkan dengan native ligand. Hal ini menunjukkan bahwa senyawa sianidin dan peonidin yang terkandung dalam ubi jalar ungu mempunyai potensi sebagai agen depigmentasi melalui penghambatan protein D-Dopachrome taumerase secara in silico.
\end{abstract}

Kata Kunci: sianidin, peonidin, depigmentasi, in silico, molecular docking.

\begin{abstract}
Hyperpigmentation is caused by enhancement of melanin production that causes skin darkening. Purple sweet potato is one of the plants that is potentially developed as skin depigmentation agent because it contains anthocyanin. The most common types of anthocyanins in purple sweet potato are cyanidin and peonidin which are in vitro proven to be used as skin lightening. The objective of this study is to determine the potential of cyanidin and peonidin as skin depigmentation agent against target protein D-Dopachrome taumerase through in silico molecular docking method. The research steps include the preparation of target protein using Chimera 1.10.1 program, optimization of cyanidine and peonidin 3D structures using Hyperchem 8 program, validation of molecular docking method, and docking of cyanidine and peonidine on target protein using Autodock 4.2 program. The bond energy between cyanidin and peonidin with the target protein D-Dopachrome taumerase are $-7.75 \mathrm{kcal} / \mathrm{mol}$ and $-8.38 \mathrm{kcal} / \mathrm{mol}$. The cyanidin and peonidin bond values are smaller than the native ligand, suggesting that the bond between the test compound (cyanidin and peonidin) with the target protein are stronger and more stable than the native ligand, so that the affinity of the test compound was greater than the native ligand. This suggests that the cyanidin and peonidin compounds in purple sweet potato have potential as a depigmentation agent by inhibiting $D$-Dopachrome taumerase protein.
\end{abstract}

Keyword : cyanidin, peonidin, depigmentation, in silico, molecular docking

\section{PENDAHULUAN}

Hiperpigmentasi merupakan suatu
proses yang disebabkan oleh adanya

peningkatan produksi melanin yang menyebabkan penggelapan warna kulit. Penggelapan kulit yang disebabkan oleh proses hiperpigmentasi merupakan masalah kulit yang 
paling umum dialami oleh orang-orang di Asia (Kurita et al., 2009). Kulit yang gelap menimbulkan beberapa masalah bagi seseorang diantaranya adalah kurang percaya diri terhadap penampilannya, sehingga banyak orang yang melakukan usaha untuk mencerahkan warna kulit, salah satunya dengan menghambat proses pembentukkan melanin (Lloyd et al., 2011).

Produksi melanin di dalam tubuh diatur oleh beberapa enzim, diantaranya adalah enzim D-Dopachrome tauomerase. Enzim ini berperan dalam mengubah senyawa dopakrom menjadi 5,6 dihidroxyindole-2-carboxy acid (DHICA). DHICA kemudian diubah menjadi Indole-5,6-quinone carboxylic acid oleh tyrosinase related protein 1 untuk membentuk eumelanin (pigmen berwarna coklat) (Gillbro dan Alsson, 2010). Sehingga, penghambatan pada enzim D-Dopachrome tauomerase dapat menjaga kecerahan kulit dengan mengurangi produksi eumelanin.

Produk pencerah kulit saat ini banyak beredar di pasaran dengan berbagai bahan aktif agen depigmentasi. Agen depigmentasi yang banyak digunakan pada produk pencerah kulit yang beredar di pasaran adalah hidrokuinon, asam azelaik, dan asam kojat. Penggunaan bahan-bahan tersebut dapat menimbulkan beberapa efek samping seperti alergi, iritasi, dermatitis, rasa terbakar pada kulit bahkan kanker kulit, dan hiperpigmentasi tertentu saat agen depigmentasi dihentikan (Nakagawa et al., 1995; Raynaud et al., 2001). Dengan adanya efek samping akibat penggunaan agen depigmentasi tersebut, maka perlu dikembangkan suatu agen depigmentasi yang efektif untuk mencerahkan kulit dengan efek samping yang lebih sedikt. Salah satu agen depigmentasi yang dapat dikembangkan adalah agen depigmentasi dari bahan alam.

Ubi ungu (Ipomoea batatas L.) merupakan salah satu tanaman dengan komoditas yang cukup besar di Indonesia dengan produktivitas sebesar 2,092 juta ton pada tahun 2013. Ubi ungu berpotensi untuk dikembangkan menjadi agen depigmentasi. Berdasarkan penelitian yang dilakukan oleh Masuda et al. (2007), ekstrak etanol ubi ungu (Ipomoea batatas L) dapat menghambat aktivitas enzim tirosinase sebesar 5,4\%, dimana enzim tirosinase merupakan salah satu enzim yang berperan sebagai katalis dalam pembentukan melanin melalui pembentukan senyawa dopakuinon (Fais et al., 2009). Antosianin merupakan senyawa golongan flavonoid yang memberikan warna ungu pada ubi ungu yang diketahui memiliki berbagai aktivitas farmakologis. Umbi ubi jalar ungu memiliki kandungan antosianin yang paling tinggi dibandingkan dengan jenis umbi ubi jalar lainnya, yaitu sebesar $110,51 \mathrm{mg} / 100$ gram (Ginting et al., 2011). Jenis antosianin yang telah berhasil diisolasi dan paling banyak terkandung dalam umbi ubi jalar ungu adalah sianidin dan peonidin yang terikat dengan gugus gula (Montilla et al., 2011). Fraksi antosianin dari ubi ungu yang mengandung senyawa aktif peonidin diketahui dapat menginduksi enzim glutation peroksidase (GPX) yang berperan dalam pemecahan ROS (Reactive Oxygen Species) secara in silico (Laksmiani et al., 2016). ROS inilah yang diketahui mampu menginduksi aktivitas tirosinase sehingga terjadi peningkatan proses melanogenesis (Davids et al., 2016). Oleh karena itu, senyawa antosianin (sianidin dan peonidin) yang terdapat pada ubi ungu berpotensi untuk dikembangkan sebagai agen depigmentasi.

Untuk mengetahui aktivitas sianidin dan peonidin sebagai agen depigmentasi, maka perlu dilakukan uji pendahuluan menggunakan metode molecular docking. Metode molecular docking ini merupakan bagian dari kimia komputasi yang memiliki keunggulan yaitu aman, bebas dari penggunaan bahan kimia, serta dapat menghemat waktu dan biaya penelitian (Makheswari dan Sudarsanam, 2012). Jadi penggunaan metode ini dapat meningkatkan efektivitas penelitian dalam pengembangan agen depigmentasi. Penggunaan metode molecular docking juga dapat memprediksi afinitas dan mekanisme dari senyawa sianidin dan peonidin terhadap preotein target yang berpengaruh terhadap aktivitasnya. Oleh karena itu, simulasi dengan komputasi ini sangat penting dilakukan untuk mengetahui potensi serta mekanisme dari sianidin dan peonidin sebagai agen depigmentasi kulit secara in silico.

\section{BAHAN DAN METODE}

Bahan

Struktur enzim D-Dopachrome tauomerase (PDB ID : 3KAN) yang diunduh dari http://www.rcsb.org/pdb/home.do serta 
struktur 3 dimensi dari sianidin dan peonidin yang diGambar menggunakan aplikasi Hyperchem 8

\section{Alat}

Seperangkat komputer dengan spesifikasi Windows 864 bit dan program Autodock 4.2, Open Babel, Chimera 1.10.1, dan HyperChem 8

\section{Metode Penelitian}

\section{Optimasi Struktur 3D Sianidin dan Peonidin}

Struktur senyawa sianidin dan peonidin yang sudah diGambar kemudian dioptimasi dengan menggunakan program HyperChem 8. Metode komputasi yang digunakan adalah metode komputasi semi-empiris AM1, dan kalkulasi dengan single point serta geometri optimisasi.

\section{Preparasi Struktur Protein}

Proses preparasi enzim D-Dopachrome tauomerase dengan memisahkan native ligand dari struktur protein menggunakan aplikasi Chimera 1.10.1.

\section{Validasi Metode Docking Molecular}

Validasi metode docking molecular dilakukan dengan men-docking-kan kembali Native ligand pada enzim yang sudah dihilangkan native ligand-nya menggunakan program Autodock 4.2 dengan parameter RMSD. Jika nilai Root mean square distances (RMSD) $\leq 3 \AA$, protokol diterima dan docking senyawa uji pada enzim target dapat dilakukan (Jain dan Nicholls, 2008).

\section{Docking Sianidin dan Peonidin pada Enzim D-Dopachrome tauomerase}

Senyawa uji sianidin dan peonidin hasil optimasi selanjutnya di-docking-kan pada protein yang sudah dihilangkan native ligandnya menggunakan program Autodock 4.2. Hasil analisis akan menunjukkan konformasi energi ikatan terendah untuk berikatan dengan protein target

\section{Analisis Data}

Hasil docking molecular adalah energi ikatan. Nilai energi ikatan menunjukkan kekuatan ikatan antara senyawa dan reseptor. Semakin rendah harga energi ikatan, maka ikatannya semakin kuat dan stabil.

\section{HASIL DAN PEMBAHASAN}

Optimasi Struktur 3D Sianidin dan
Peonidin

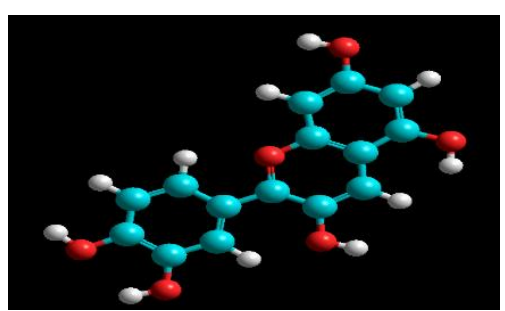

(a)

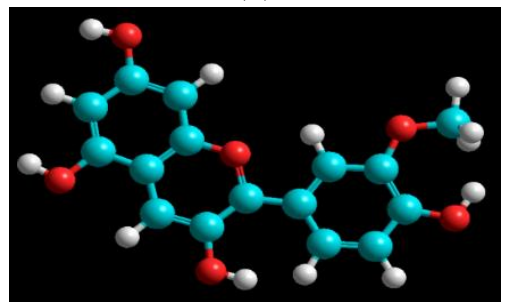

(b)

Gambar 1. Hasil Optimasi Struktur 3 Dimensi Senyawa Sianidin (a) dan Peonidin (b)

Optimasi struktur yang telah diunduh dilakukan dengan menggunakan program Hyperchem 8. Optimasi struktur 3D sianidin dan peonidin dilakukan metode kalkulasi AM1 (Austin model 1) dan kalkulasi single point serta geometry optimization untuk mendapatkan struktur senyawa sianidin dan peonidin yang paling stabil dengan total energi terendah. Besar energi total hasil kalkulasi single point yang diperoleh untuk sianidin dan peonidin berturut-turut adalah $-3610,159$ $\mathrm{kkal} / \mathrm{mol}$ dan $-3698,098 \mathrm{kkal} / \mathrm{mol}$. Setelah diperoleh energi total dari kalkulasi single point sianidin dan peonidin, kemudian dilanjutkan dengan optimasi geometri. Besar energi hasil optimasi geometri yang diperoleh untuk sianidin dan peonidin berturut-turut adalah $-3653,797 \mathrm{kkal} / \mathrm{mol}$ dan $-3910,095$ $\mathrm{kkal} / \mathrm{mol}$. Dalam proses optimasi geometri ini, energi total sianidin dan peonidin diminimalisir untuk mendapatkan struktur yang paling stabil (Fitriasari et al., 2008). Hasil dari optimasi struktur sianidin dan peonidin ditunjukkan pada Gambar 1.

\section{Preparasi Enzim D-Dopachrome tauomerase}

Preparasi dilakukan dengan memisahkan native ligand dari struktur protein menggunakan program Chimera 1.10.1 sehingga dihasilkan struktur enzim $D$ - 
Dopachrome tauomerase tanpa native ligandnya dan struktur native ligand yang terpisah seperti Gambar 2. Pemisahaan native ligand dari struktur protein bertujuan untuk menyediakan pocket yang nanti digunakan sebagai ruang tempat berikatan senyawa uji (sianidin dan peonidin) pada protein target $D$ Dopachrome tauomerase.

\section{Validasi Metode}

Validasi metode molecular docking dilakukan dengan redocking native ligand pada enzim tirosinase tanpa native ligand menggunakan Autodock 4.2. Pada proses validasi, diperoleh 10 konformasi ikatan native ligand pada protein target. Dari 10 konformasi tersebut, dipilih satu konformasi dengan nilai RMSD (Root Mean Square Deviation) yang paling rendah. RMSD merupakan ukuran yang menyatakan penyimpangan posisi ikatan native ligand yang diperoleh secara eksperimental dibandingkan dengan yang sebenarnya. Semakin besar nilai RMSD, maka penyimpangan posisi ikatan juga semakin besar sehingga kemungkinan kesalahan prediksi ikatan saat dilakukan docking senyawa uji juga semakin besar. Nilai RMSD yang diperolah pada penelitian ini adalah sebesar 2,42 ̊. Suatu metode molecular docking dikatakan valid apabila memiliki nilai RMSD $\leq 3 \AA$ (Jain dan Nicholls, 2008). Berdasarkan hasil yang didapat, maka metode molecular docking yang digunakan pada penelitian ini sudah valid dan dapat digunakan untuk docking senyawa sianidin dan peonidin pada enzim D-Dopachrome tauomerase. Visualisasi interaksi validasi metode molecular docking dapat dilihat pada Gambar 3.

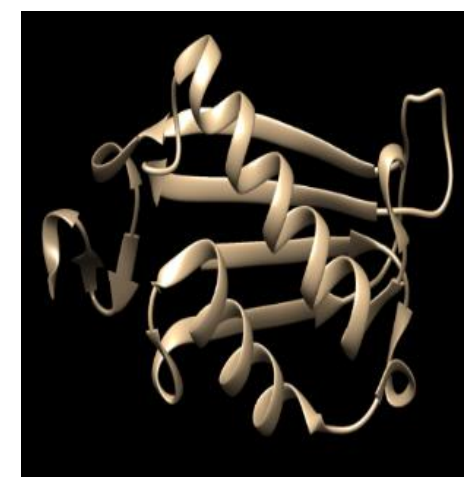

(a)

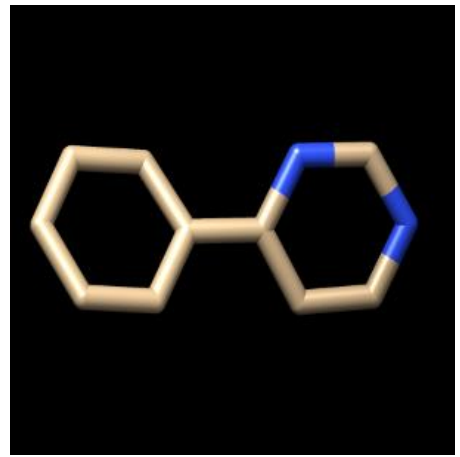

(b)

Gambar 2. Struktur Enzim D-Dopachrome tauomerase tanpa native ligand (a) dan native ligand (b)

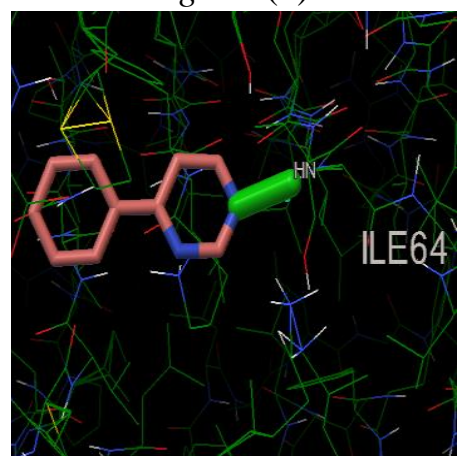

Gambar 3. Visualisasi interaksi antara native ligand dengan enzim $D$-Dopachrome tauomerase

\section{Docking Sianidin dan Peonidin pada Enzim D-Dopachrome tauomerase}

Senyawa sianidin dan peonidin yang telah teroptimasi di-docking-kan pada enzim D-Dopachrome tauomerase tanpa native ligand menggunakan Autodock 4.2 pada kordinat yang sama dan telah tervalidasi pada saat validasi metode. Proses docking sianidin dan peonidin pada enzim D-Dopachrome tauomerase menghasilkan 10 konformasi ikatan sianidin dan peonidin dengan enzim $D$ Dopachrome tauomerase. Dari 10 konformasi yang didapatkan tersebut, dipilih satu konformasi yang mempunyai energi ikatan yang paling rendah, yang menunjukkan konformasi dengan ikatan paling stabil. Perbandingan hasil dan visualisasi interaksi docking yang terjadi antara sianidin dan peonidin dengan enzim D-Dopachrome tauomerase dapat dilihat pada tabel 1 dan Gambar 4. Afinitas suatu senyawa pada protein target dapat diketahui dengan membandingkan energi ikatan senyawa uji dengan native 
ligand. Apabila suatu senyawa memiliki energi ikatan yang lebih rendah dibandingkan dengan native ligand, maka ikatan yang terbentuk antara senyawa tersebut dengan protein terget lebih kuat dibandingkan dengan ikatan antara native ligand dengan protein target (Laksmiani et al., 2016). Hal ini menunjukkan afinitas senyawa tersebut lebih besar dibandingkan dengan native ligand. Berdasarkan hasil penelitian yang didapatkan, diketahui bahwa senyawa sianidin dan peonidin memiliki nilai energi ikatan yan lebih kecil dibandingkan dengan native ligand. Hal ini menunjukkan bahwa sianidin dan peonidin memiliki afinitas yang lebih besar dibandingkan dengan native ligand, sehingga sianidin dan peonidin secara in silico memiliki aktivitas sebagai agen depigmentasi dan berpotensi untuk dikembangkan.

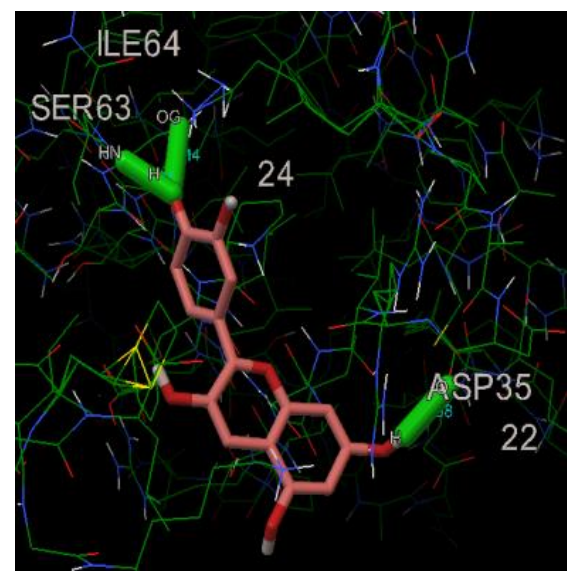

(a)

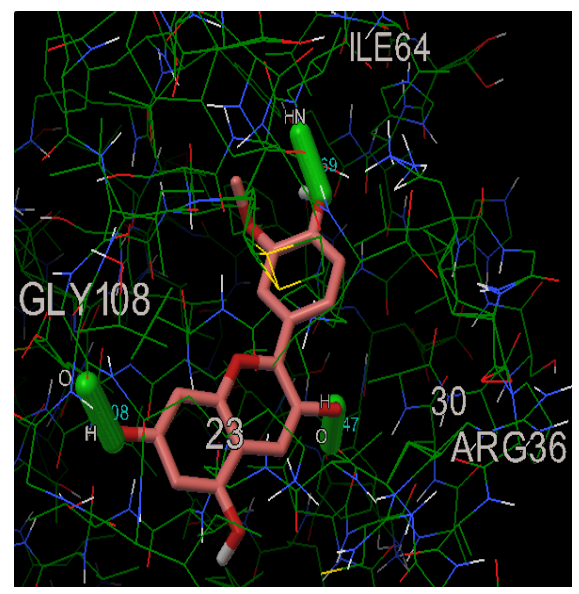

(b)

Gambar 4. Visualisasi Interaksi dengan enzim D-Dopachrome tauomerase dengan sianidin (a) dan peonidin (b).
Tabel 1. Hasil Docking antara sianidin dan peonidin dengan enzim $D$-Dopachrome

\begin{tabular}{|c|c|c|c|}
\hline \multicolumn{4}{|c|}{ tauomerase } \\
\hline Ligan & $\begin{array}{c}\text { Energi } \\
\text { Ikatan } \\
\text { (Kkal/mol) }\end{array}$ & $\begin{array}{c}\text { RMSD } \\
(\AA)\end{array}$ & $\begin{array}{c}\text { Ikatan } \\
\text { Hidrogen }\end{array}$ \\
\hline $\begin{array}{l}\text { Native } \\
\text { ligand }\end{array}$ & $-6,48$ & 2,42 & ILE64 \\
\hline Sianidin & $-7,75$ & 9,37 & $\begin{array}{l}\text { ILE64 } \\
\text { ASP35 } \\
\text { SER63 }\end{array}$ \\
\hline Peonidin & $-8,38$ & 8,83 & $\begin{array}{c}\text { ARG36 } \\
\text { ILE64 } \\
\text { GLY108 }\end{array}$ \\
\hline
\end{tabular}

\section{KESIMPULAN}

Sianidin dan peonidin memiliki potensi sebagai agen depigmentasi secara in silico dengan nilai energi ikatan yang terbentuk sebesar $-7,75 \mathrm{kkal} / \mathrm{mol}$ (sianidin) dan $-8,38$ $\mathrm{kkal} / \mathrm{mol}$ (peonidin).

\section{UCAPAN TERIMA KASIH}

Penulis mengucapkan terimakasih kepada dosen-dosen, keluarga penulis, temanteman dan semua pihak yang telah sangat membantu dalam penelitian ini

\section{DAFTAR PUSTAKA}

Davids, I. M., J. C. van Wyk, dan N. P. Khumalo. 2016. Intravenous glutathione for skin lightening: Inadequate safety data. SAMJ 106(8): 782-787

Fais, A., M. Corda, B. Era, M. B. Fadda, M. J. Matos, E. Quezada, L. Santana, C. Picciau, G. Podda, dan G. Delogu. 2009. Tyrosinase Inhibitor Activity of Coumarin-Resveratrol Hybrids. Molecules 14: 2514-2520.

Fitriasari, A., N. K. Wijayanti, N. Ismiyati, D. Dewi, W. Kundarto, B. S. A. Sudarmanto dan E. Meiyanto. 2008. Studi Potensi Kurkumin dan Analognya sebagai Selective Estrogen Receptor Modulator (SERMs): Docking pada Reseptor Estrogen B. Pharmacon 9(1)

Gillbro, J. M., dan M. J. Olsson. 2010. The Melanogenesis and Mechanisms of Skin-Lightening Agents - Existing and 
New Approaches. International Journal of Cosmetic Science 33: 210-221

Ginting, E., J. S. Utomo, R. Yulifianti, dan M. Jusuf. 2011. Potensi Ubi Jalar Ungu sebagai Pangan Fungsional. Iptek Tanaman Pangan 6(1): 116-138.

Jain, A. J., dan A. Nicholls. 2008. Recommendations for evaluational methods. J. Comput. Aided Mol 22: 133139

Kurita, M., H. Kato, dan K. Yoshimura. 2009. A Therapeutic Strategy Based on Histological Assessment of Hyperpigmented Skin Lesions in Asians. Journal of Plastic, Reconstructive and Aesthetic Surgery 62: 955-963

Laksmiani, N. P. L., N. L. P. V. Paramita, dan I. M. A. G. Wirasuta. 2016. In Vitro and In Silico Antioxidant Activity of Purified Fractions from Purple Sweet Potato Ethanolic Extract. International Journal of Pharmacy and Pharmaceutical Sciences 8(8): 177-181

Lloyd, H. W., N. Jenna, dan B. A. Kammer. (2011). Treatment of Hyperpigmentation. Semin Cutan Med Surg 30: 171-175

Makheswari, U. dan Sudarsanam D. 2012. A Review on Bio Informatics for Diabetic
Mellitus. International Journal of Pharma Sciences and Research. Vol.3(6): 1-6

Masuda, T., N. Fujita, Y. Odaka, Y. Takeda, S. Yonemori, K. Nakatomo, dan $\mathrm{H}$. Kuninaga. 2007. Tyrosinase Inhibitory Activity of Ethanol Extracts from Medicinal and Edible Plants Cultivated in Okinawa and Identification of A Water-Soluble Inhibitor From the Leaves of Nandina Domestica. Bioscience, Biotechnology, and Biochemistry 71(9): 2316-2320

Montilla, E. C., S. Hillebrand dan P. Winterhalter. 2011. Anthocyanins in Purple Sweet Potato Varieties. Fruit, Vegetable and Cereal Science and Biotechnology 5(2): 19-24

Nakagawa, M., K. Kawai, dan K. Kawai. 1995. Contact Allergy to Kojic Acid in Skin Care Products. Contact Dermatitis 32(1): 9-13

Raynaud, E., C. Cellier, dan J. L. Perret. 2001. Depigmentation for Cosmetic Purposes: Prevalence and Side-Effects in A Female Population in Senegal. Annales de Dermatologie et de Venereologie 128(6-7):720-724 